\title{
PENGGUNAAN BAR MODELUNTUK MENINGKATKAN \\ KEMAMPUAN MEMBUAT MODEL MATEMATIS \\ DAN KETERAMPILAN PROSEDURAL \\ SERTA KETEKUNAN BELAJAR SISWA SEKOLAH DASAR
}

\author{
Rosiana Mufliva dan Tatang Herman \\ Email: rosianamufliva@gmail.com
}

\begin{abstract}
The purpose of this study was to obtain an overview of the differences in the increase in the ability to create mathematical models and procedural skills students acquire bar model and learning with hands-on learning, as well as a description of the persistence of student learning with the learning gained iconic models. The method used in this study is a quasi-experimental non-equivalent control group pretest-posttest desig. The subject of research for each class are the same ie 25 student. Based on the findings in the field, it can be concluded that by using iconic models may improve the ability to create a mathematical model, the mathematical procedural skills and perseverance of student learning. It is evident from the $N$-Gain score for the experimental class - upon ability capability that is higher than the score of $N$ - Gain control class.

Keywords:bar model, mathematical model ability, mathematical procedural skills, learning perseverance
\end{abstract}

\begin{abstract}
ABSTRAK
Tujuan penelitian ini adalah untuk memperoleh gambaran mengenai perbedaan peningkatan kemampuan membuat model dan keterampilan prosedural matematis siswa yang memperoleh pembelajaran dengan bar model dan pembelajaran langsung, serta gambaran mengenai ketekunan belajar siswa yang memperoleh pembelajaran dengan bar model. Metode yang digunakan dalam penelitian ini adalah kuasi eksperimen non equivalent control group pre-test post test design. Subjek penelitian untuk masing-masing kelas adalah sama yaitu 25 siswa. Berdasarkan temuan di lapangan, dapat disimpulkan bahwa dengan menggunakan bar model dapat meningkatkan kemampuan membuat model matematis, keterampilan prosedural matematis dan ketekunan belajar siswa. Hal ini terbukti dari skor $\mathrm{N}$-Gain kelas eksperimen untuk kemampuan-kemmapuan tersebut yang lebih tinggi dari skor $N$-Gain kelas kontrol.
\end{abstract}

Kata Kunci:bar model, kemampuanmembuat model matematis, keterampilan prosedural matematis, ketekunan belajar

\section{PENDAHULUAN}

NCTM (2000) mengemukakan bahwa "pengetahuan matematis baru harus dibangun melalui pemecahan masalah, bahwa penalaran dan pembuktian adalah aspek-aspek fundamental dari matematika, bahwa para siswa dapat menyusun dan menggabungkan pengetahuan matematis dengan strategistrategi yang bermuatan pedagogis".Oleh karena itu, peran guru menjadi sangat fundamental dalam membentuk suatu situasi belajar yang dapat mengaktifkan siswa dan mengembangkan kemampuan penalarannya. Apabila siswa mampu membuat keterkaitan antara ide-ide matematis, maka pemahaman mereka terhadap matematika akan lebih mendalam serta bertahan lama (Wahyudin dalam Badjeber \& Siti, 2015 hlm. 19).

Untuk dapat membuat pemahaman siswa terhadap matematika lebih mendalam, diperlukan suatu proses pembelajaran yang baru yang benar-benar dipikirkan oleh guru, seperti yang dikemukakan oleh Turmudi (2012 hlm. 5) yang mengemukakan bahwa "inovasi dalam pembelajaran matematika cenderung berkaitan dengan tiga hal yaitu bagaimana memahami matematika, bagaimana mengajar matematika, dan bagaimana menilai pemahaman matematika. Inovasi dalam pembelajaran matematika ini sejalan dengan pendapat Wismath, Doug \& Bruce (2015, hlm. 64) yang mengemukakan bahwa "kompetensi pedagogik dalam diri guru mutlak diperlukan dan dapat digunakan sebagai strategi yang jitu untuk membantu siswa dalam mengubah sikapnya terhadap matematika dan juga dapat digunakan sebagai strategi pembelajaran untuk meningkatkan 
kemampuan pemecahan masalah siswa". Jadi, seorang guru harus memiliki inovasi dalam pembelajaran matematika, baik berupa strategi pembelajaran atau model pembelajaran, juga kompetensi pedagogik dalam meningkatkan kemampuan pemecahan masalah dan penalaran siswa.

Siswa dapat memecahkan suatu masalah apabila ia memiliki kemampuan memahami soal yang baik dan juga penalaran yang baik, sehingga ia dapat membuat model matematisnya dan mengerjakan soal tersebut secara prosedural. Hal ini sejalan dengan pendapat English dan Watters (2005, hlm. 60) yang mengemukakan bahwa "modelling activities are espoused to foster mathematical reasoning processes". Artinya bahwa proses pembelajaran yang di dalamnya terdapat kegiatan memodelkan suatu masalah matematika menjadi suatu gambar, dapat mempercepat proses penalaran matematika siswa. Hal ini juga didukung oleh pendapat (Alagic, 2003, hlm. 635) yang mengemukakan bahwa "students with a deep understanding of concepts are able to grasp subsequent concepts more efficiently". Jadi, siswa yang memiliki kemampuan pemahaman mengenai suatu konsep matematika yang mendalam akan memiliki kemampuan memahami konsep-konsep berikutnya lebih efisien. Selanjutnya, Herman () mengemukakan bahwa "pengetahuan konseptual dan prosedural merupakan unsur esensial dalam belajar matematika".

Selain itu, penelitian telah menunjukkan bahwa para siswa yang berorientasi pada pengetahuan konsep mengalahkan para siswa yang berorientasi pada pengetahuan prosedur pada tes-tes ukuran sikap terhadap matematika (Cain dalam Wahyudin, 2013, hlm. 14). Berdasarkan hasil penelitian tersebut, tergambar jelas bahwa tugas seorang guru dalam proses pembelajaran terhadap siswa sangatlah berat. Hal ini dikarenakan kita harus menanamkan konsep secara mendalam dalam diri siswa, sehingga ia dapat melakukan prosedur- prosedur matematika dengan baik. Untuk dapat memahami konsep secara mendalam, siswa harus memiliki kemampuan penalaran yang baik pula. Hasil penelitian Cain (dalam Wahyudin, 2013, hlm. 14) tersebut didukung oleh hasil penelitian Turmudi (2012, hlm. 11) yang menunjukkan bahwa umumnya siswa bersikap positif terhadap pembelajaran matematika menggunakan pemodelan berbasis realistik. Umumnya para guru merasa tertarik untuk membelajarkan siswa menggunakan pemodelan karena melalui pendekatan ini bisa menemukan hal-hal baru yang tidak terduga (re-invention), dapat menyaksikan matematika dalam aktivitas menusia, serta dapat melihat matematika aplikasi.

Mendukung hasil penelitian Turmudi (2012, hlm. 11), Fong \& Lee (2009, hlm. 170) mengemukakan bahwa kita harus mendukung perkembangan berfikir aljabar anak-anak sejak masa kelas rendah untuk membantu mereka memasuki masa peralihan antara aritmatika dan aljabar dengan halus dengan cara membantu mereka menghargai kegunaan pendekatan aljabar dalam memecahkan soal. Hal ini sesuai dengan pendapat Bruner (1964, hlm. 3), yang mengemukakan bahwa dalam proses belajarnya anak melewati tiga tahap, yaitu: 1) Tahap enactive: pada tahap belajar ini anak secara langsung terlihat dalam memanipulasi (mengotak-atik) objek; 2) tahap iconic: pada tahap belajar ini kegiatan yang dilakukan anak berhubungan dengan mental, yang merupakan gambaran dari objek-objek pada tahap sebelumnya. Dengan kata lain anak dapat membayangkan kembali atau memberikan gambaran dalam pikirannya tentang benda atau peristiwa yang dialami yang dikenalnya pada tahap enaktif; 3) tahap symbolic: pada tahap ini siswa sudah mampu menggunakan notasi atau simbol tanpa ketergantungan terhadap objek riil. Jadi apabila ia melihat suatu simbol maka bayangan mental yang ditandai oleh simbol itu akan dikenalnya kembali.

Newman (dalam Chen, 2013) 
mengemukakan lima langkah dalam menyelesaikan word problem, yaitu: (a) membaca masalah; (b) memahami apa yang dibaca; (c) mentransformasi kata ke dalam strategi matematika; (d) menerapkan prosedur matematika; dan (e) menuliskan jawaban. Di dalam penelitiannya, Newman menemukan bahwa para siswa lebih dari 50\% nya menunjukkan kegagalan pada tiga langkah pertama, bahkan sebelum mereka memulai memecahkan masalah. Jadi, berdasarkan penelitian tesebut,para siswa merasakan kesulitan dalam merepresentasikan soal ke dalam simbol formal aljabar.Berdasarkan paparan tersebut, salah satu kemampuan yang penting untuk dikembangkan pada siswa Sekolah Dasar adalah kemampuan membuat model matematis yang merupakan bagian dari kemampuan penalaran dan kemampuan proseduralyang merupakan bagian dari kecakapan matematis. Ketika siswa dapat membuat model matematis, artinya siswa sudah memperoleh atau memiliki pengetahuan konseptual yang kuat. Sehingga, siswa dapat merepresentasikan masalah yang ada dalam pertanyaan matematika menjadi suatu model matematika. Selanjutnya, ketika siswa sudah dapat membuat pemodelan dan menginterpretasikan model tersebut dalam suatu prosedur matematika, artinya siswa sudah memiliki pengetahuan prosedural yang kuat pula. Namun, kedua kemampuan tersebut juga harus didukung oleh sikap siswa yang tekun dalam pembelajaran matematika. Sehingga, kedua kemampuan tersebut dapat lebih terasah dan tertanam dalam diri siswa.

Hasil penelitian Newman (dalam Chen, 2013) mengenai rendahnya kemampuan pemecahan masalah pada tiga langkah pertamanya, juga sesuai dengan hasil observasi pembelajaran matematika yang peneliti lakukan di Sekolah Dasar, bahwa siswa-siswa kelas tinggi merasa kesulitan ketika disajikan pertanyaan-pertanyaan yang memuat indikator kemampuan penalaran. Bahkan sebagian besar siswa kurang memahami maksud soal. Sehingga, siswa belum dapat merepresentasikan dan menginterpretasikan soal tersebut dalam upaya memperoleh jawaban yang tepat. Hal ini, salah satunya dikarenakan kurangnya pembiasaan pembelajaran dengan mengembangkan kemampuan penalaran siswa. Selain itu, siswa tidak rutin mendapatkan soal-soal yang memuat indikator kemampuan tersebut. Sehingga siswa merasa kesulitan dalam memecahkan pertanyaan tersebut dan para siswa juga cenderung kurang tekun.

Untuk dapat mengembangkan kemampuan membuat model matematis dan prosedural matematis, siswa harus memperoleh pembelajaran yang efektif. Hal ini sesuai dengan pendapat Ginsburg, Steven, Terry \& Elizabeth (2005, hlm. 1) yang mengemukakan bahwa "... be able to use mathematical knowledge, include representing a problem mathematically, reasoning through the logic of a solution, and communicating mathematical content".

Mahoney (2012, hlm. 5) mengemukakan bahwa "in mathematics education, the phase most often ignored by educators is the iconic phase. This "pictorial" stage acts as a bridge between the concrete and the abstract. Artinya bahwa untuk membantu siswa agar dapat melalui tahap iconic dengan baik, maka diperlukan suatu model pembelajaranyang dapat menjembatani antara konkrit ke abstrak. Moone (2007, hlm. 266)yang mengemukakan bahwa "fractions are often difficult mathematical concepts for children". Sehingga peneliti mengambil materi penjumlahan dan pengurangan pecahan untuk siswa kelas IV SD sesuai dengan fakta di lapangan dan kajian literatur yang dilakukan untuk penelitian ini.

Untuk mengembangkan kemampuan siswa pada saat belajar, khususnya pada tahap iconic, diperlukan kiranya suatu model pembelajaran yang dapat menunjang dan mengakomodir kebutuhan siswa dalam meningkatkan kemampuan tersebut. Para praktisi dan pakar pendidikan di Singapura 
mendesain suatu metode yang dapat menjembati hal tersebut, yaitu dengan menggunakan model gambar atau bar model. Menurut Kho (dalam Fong dan Lee, 2009, hlm. 172) "the method can be used as a tool for solving both aritmetics and algebraic word problems involving whole numbers, fraction, rations and percents." Jadi, bar model ini dapat digunakan sebagai alat untuk memecahkan masalah aritmatika dan aljabar.

Alasan penggunaan bar model ini digunakan sebagai alat untuk membantu membuat model dari masalah matematis adalah karena dapat membantu siswa memvisualisasi relasi abstrak matematika ke dalam bentuk gambar, menggunakan blok persegi panjang karena mudah dibagi, dapat digunakan sebelum siswa mengetahui solusi secara aljabar. Dengan kata lain, sebagai jembatan perantara menuju proses aljabar formal. (Fong dan Lee, 2009, hlm. 172).

Penelitian Cheong (2002, hlm. 62) menunjukkan bahwa bar model dapat memecahkan banyak masalah aritmetika yang menantang. Hal ini sejalan dengan hasil penelitian Thirunavukkarasu \& Senthilnathan (2014, hlm. 20) yang menunjukkan bahwa pembelajaran dengan menggunakan bar model sangat efektif dalam meningkatkan kemampuan pemahaman matematika siswa Sekolah Dasar. Penelitian Fong \& Kerry (2009) juga menunjukkan bahwa pembelajaran matematika dengan menggunakan bar model dapat meningkatkan kemampuan membuat model matematis dan mendukung kemampuan siswa dalam menyelesaikan masalah matematika di Sekolah Dasar.

Selain itu, Fong \& Kerry (2009, hlm. 172) juga mengungkapkan bahwa bar model merupakan model pembelajaranyang dapat memberikan analog visual yang menggambarkan seluruh informasi di dalam soal dengan menggunakan bar atau persegi panjang. Siswa menggunakan struktur bar model untuk membantu mereka dalam mengkonstruksi setiap langkah prosedur aritmatika untuk mencari penyelesaian masalah secara aktif dengan mudah. Bar model ini dikarenakan lebih mudah dalam penyampaian konsep dan menerapkannya pada siswa. Untuk materi pecahan penggunaan bar model ini lebih memudahkan siswa dalam membagi setiap barnya menjadi bagian yang sama besar.

\section{METODE}

Penelitian yang dilakukan merupakan studi kuasi eksperimen dengan desain non equivalent control group pre-test post test design, dengan kelompok kontrol tidak dipilih secara random (Sugiyono, 2009, hlm. 116). Dalam penelitian ini sampel tidak diambil secara acak. Sehingga peneliti memilih sendiri untuk menentukan sampel penelitian yaitu siswa kelas IV SDN Kec. astana Anyar.

Instrumen yang digunakan dalam penelitian ini adalah instrumen tes yang terdiri dari instrumen kemampuan membuat model matematis dan instrumen keterampilan prosedural siswa. Sedangkan instrumen non tes terdiri dari angket dan lembar observasi ketekunan belajar siswa.

\section{HASIL DAN PEMBAHASAN}

\section{Kemampuan Membuat Model Matematis}

Skor pre-test kemampuan membuat model matematis kelas eksperimen dan kelas kontrol disajikan dalam tabel 1.

Berdasarkan data pada tabel 1 jumlah sampel kedua kelas adalah sama yaitu 25 siswa. Pada rata-rata skor pre-test kemampuan membuat model matematis kelas eksperimen memiliki nilai rata-rata 11,28 dan lebih tinggi dari rata-rata kelas kontrol yang hanya memiliki nilai rata-rata 9,96. Selisih rata-rata antara kedua kelas adalah 1,32 yang apabila dikonversikan dalam bentuk persentase pencapaian kelas eksperimen adalah 47\% atau 6,5\% lebih tinggi dari pencapaian kelas kontrol yang henya memperoleh. 41,5\%.

Berdasarkan hasil uji-t dengan skor 
Tabel 1

Skor Pre-test Kemampuan Membuat Model Matematis Kelas Eksperimen dan Kelas Kontrol

\begin{tabular}{llcccc}
\hline & $\mathrm{N}$ & Minimum & Maximum & Mean & Std. Deviation \\
\hline Eksperimen & 25 & 5 & 16 & 11.28 & 2.807 \\
\hline Kontrol & 25 & 5 & 14 & 9.96 & 2.475 \\
\hline $\begin{array}{l}\text { Valid N } \\
\text { (listwise) }\end{array}$ & 25 & & & & \\
\hline
\end{tabular}

Skor maksimal ideal $=24$

P-value (Sig. 2 tailed) $=0,082$ pada taraf signifikansi $\alpha=0,05$ karena yang diuji satu arah sehingga 0,082 dibagi dua hasilnya $=$ $0,041<0,05=\alpha$, kondisi demikian $\mathrm{H}_{0}$ ditolak artinya, terdapat perbedaan yang signifikan skor pre-test kemampuan membuat model

\section{Tabel 2}

Skor Post-test Kemampuan Membuat Model Matematis Kelas Eksperimen dan Kelas Kontrol

\begin{tabular}{lccccc}
\hline & $\mathrm{N}$ & Minimum & Maximum & Mean & Std. Deviation \\
\hline Eksperimen & 25 & 13 & 23 & 18.04 & 3.409 \\
\hline Kontrol & 25 & 7 & 18 & 13.72 & 2.509 \\
\hline Valid N (listwise) & 25 & & & & \\
\hline
\end{tabular}

Berdasarkan data pada tabel 2 jumlah sampel kedua kelas adalah sama, yaitu 25 orang siswa. Pada rata-rata skor post-test kemampuan membuat model matematis kelas eksperimen memiliki nilai rata-rata. 18,04 dan lebih tinggi dari rata-rata kelas kontrol, yang hanya memiliki nilai rata-rata 13,72. Sehingga selisih rata-rata antara kedua kelas adalah 4,32 yang apabila dikonversikan dalam bentuk persentase pencapaian kelas eksperimen adalah $75,17 \%$ atau $18 \%$ lebih tinggi daripada pencapaian rata-rata skor matematis siswa kelas eksperimen dan kelas kontrol.

Skor post-testkemampuan membuat model matematis kelas eksperimen dan kelas kontrol seperti pada tabel 2. post-test kemampuan membuat model matematis kelas kontrol yang memperoleh $57,17 \%$.

Berdasarkan hasil pre-test dan post-test terdapat perbedaan antara pencapaian ratarata skorpre-test kemampuan membuat model matematis kelas eksperimen dan kelas kontrol rata-rata post-test kemampuan yaitu sebesar 6\%. Hal ini terlihat dari pencapaian skor pre-test ke post-testkemampuan membuat model matematis pada gambar 1 .

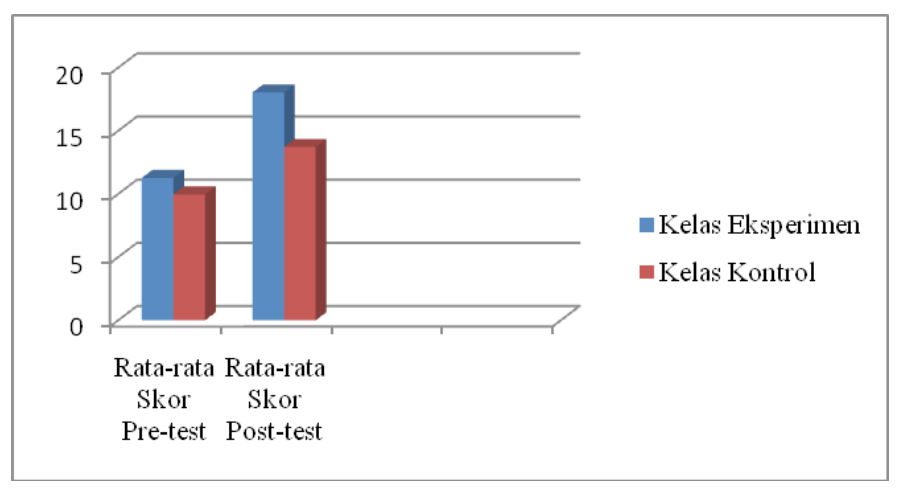

Gambar 1

Rata-rata Skor Pre-test dan Post-test Kemampuan Membuat Model Matematis Siswa Kelas eksperimen dan Kelas Kontrol

Selain itu, nilai rata-rata skorN-Gain kemampuan membuat model matematis siswa kelas eksperimen $=0,55$ atau 29\% lebih besar dibandingkan rata-rata nilai $\mathrm{N}$-Gain 
kelas kontrol $=0,26$ atau $26 \%$. Hasil uji-t skor $P$-value (sig. 2 tailed) $=0,00$ pada taraf signifikansi $\alpha=0,05$. Karena yang hasilnya 0,00 dan $0,00<0,05$, maka kondisi demikian $\mathrm{H}_{0}$ ditolak artinya terdapat perbedaan yang signifikan terhadap skor $N$-Gain kemampuan membuat model matematis siswa kelas eksperimen dan kelas kontrol; Gambar 2.

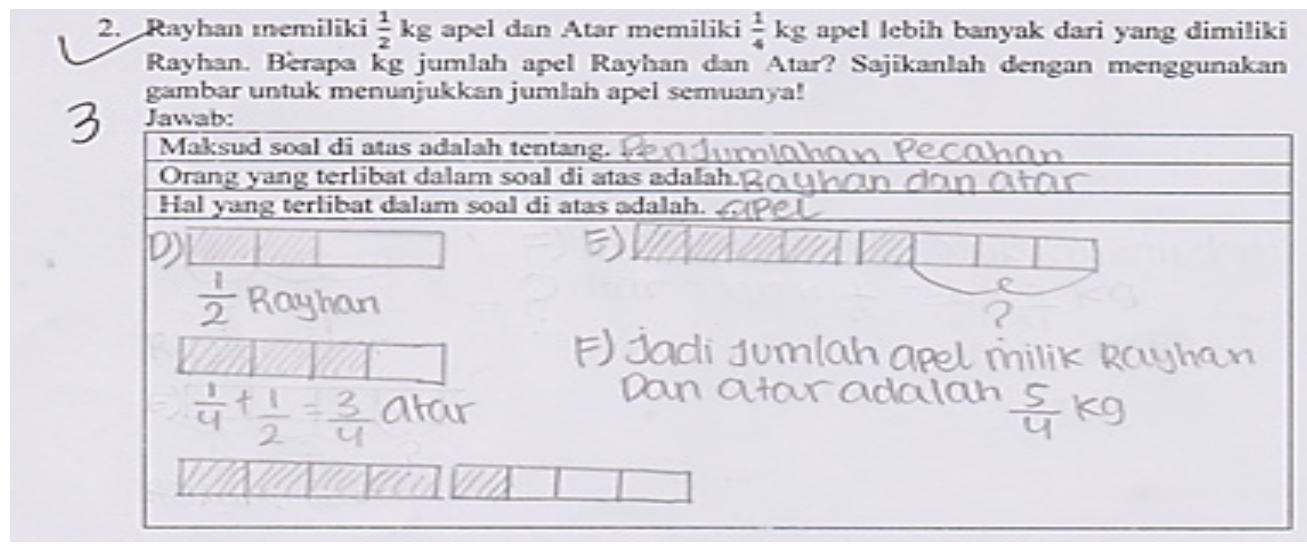

Gambar 2

Hasil Jawaban Siswa Kelas Eksperimen Pada Instrumen Post-test

Berdasarkan gambar 2 di atas, dapat dilihat bahwa dalam membuat model matematis, siswa kelas eksperimen tersebut mengerjakan soal cerita dengan sangat teliti. Mulai dari memahami maksud soal, menuliskan orang yang terlibat dalam soal, menuliskan hal yang terlibat dalam soal dan menyajikan soal tersebut dalam sebuah model matematis. Pada jawaban poin d terlihat bahwa siswa tersebut menggambar sebuah bar untuk mewakili variabel yang terlibat dalam soal.

Dalam hal ini, bar tersebut digambar untuk mewakili banyak apel milik Rayhan. Selanjutnya, siswa tersebut menggambar bar kedua untuk mewakili banyak apel milik Atar dengan cara menjumlahkan apel Rayhan denran kriteria banyak apel milik Atar, yaitu $\overrightarrow{4} \mathrm{~kg}$ lebih banyak dari banyak apel Rayhan. Dalam hal ini, siswa tersebut sudah menunjukkan kemampuan memahami maksud soal, membuat model matematis dan menunjukkan sikap ketekunan belajar. Siswa yang kurang tekun, pasti tidak akan menjumlahkan apel milik Rayhan dengan kriteria banyak apel milik Atar. Melainkanlangsung menggambarkan bahwa banyak apel milik Atar adalah ${ }^{\overline{4}} \mathrm{~kg}$. Selanjutnya, sebelum berlanjut ke poin e, siswa tersebut menyamakan penyebut pada pecahan yang terdapat dalam soal dengan menggunakan bar yang akurat. Pada poin e siswa tersebut langsung meletakkan tanda tanya pada bar yang belum diketahui jumlahnya.

Karena soal ini merupakan penjumlahan pecahan, maka siswa tersebut langsung melakukan perhitungan ke kanan dan menyimpulkan hasil penjumlahannya dengan menuliskan kalimat matematisnya. Sehingga dapat terlihat bahwa hasil jawaban siswa kelas eksperimen ini sudah runtut dan terstruktur. Dalam hal ini, siswa sudah menunjukkan kemampuan memambuat model matematis yang sangat baik. Sehingga mendapatkan skor 3 (maksimal) untuk soal nomor 2 ini. Ada pun langkah-langkah pembelajaran bar model khususnya bar model menurut Menurut Forsten (2010, hlm.1), yaitu: 1) Read the entire problem; 2) Determine who is involved in the problem; 3) Determine what is involved in the problem; 4) Draw a unit bar for each variable; 5) Place the numbers; 6) Place the question mark; 6) Do the computation to the side or underneath the unit bars; 7) Write the answer in a complete sentence.

Langkah-langkah pembelajaran inilah yang memfasilitasi dan mendukung siswa 
kelas eksperimen dalam mengembangkan kemampuan membuat model matematisnya. Dengan langkah-langkah pembelajaran bar model ini, secara bertahap, siswa dibimbing untuk memahami maksud soal, menjawab siapa dan apa yang terlibat dalam soal, menggambar atau membuat model matematis berdasarkan soal dan menyelesaikan soal tersebut dengan cara yang tepat serta dapat menuliskan kalimat matematisnya. Berbeda dengan kelas kontrol, pada kelas ini jawaban siswa ditunjukkan pada gambar 3 .

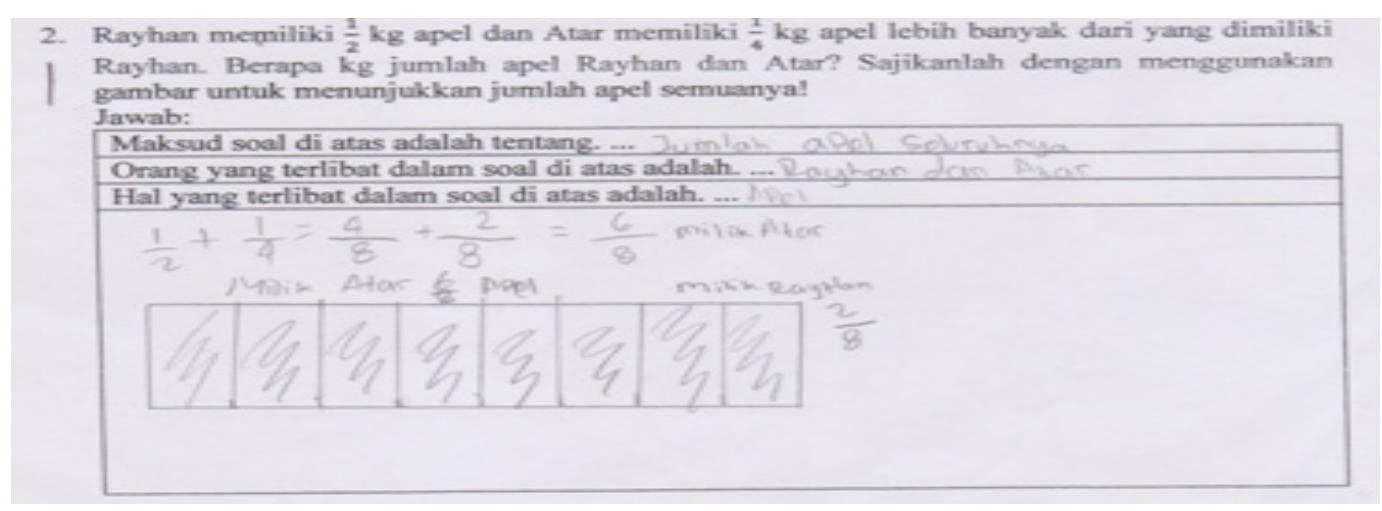

Gambar 3

Hasil Jawaban Siswa Kelas Kontrol Pada Instrumen Post-test

Berdasarkan gambar 3 di atas, siswa kelas kontrol ini sudah dapat memahami maksud soal dengan menjawab jumlah apel seluruhnya. Selanjutnya, siswa ini juga sudah dapat menuliskan orang dan hal yang terlibat dalam soal dengan tepat. Namun, selanjutnya siswa ini langsung menjumlahkan secara prosedural banyak apel milik Rayhan dan kriteria banyak apel milik Atar. Dalam hal ini, siswa tersebut sudah tepat dalam mencari banyaknya ape milik Atar yaitu dengan menjumlahkan ${ }^{4}$ $1 . \mathrm{g}$ dengan banyak apel milik Rayhan yaitu ${ }^{2} \mathrm{~kg}$. Namun, penjumlahannya dilakukan dengan menggunakan prosedur matematis. Selanjutnya siswa ini menggambar sebuah bar yang dibagi 8 dan mengarsir semua bar tersebut dan menunjukkanı bahwa bčzlyak apel milik Rayhan hanya $\overline{4} \mathrm{~kg}$ atau ${ }^{8} \mathrm{~kg}$. Artinya, siswa tersebut kurang teliti dan kurang tekun dalam mempelajari maksud soal. Sehingga siswa ini kurang menunjukkan kemampuan pemahamannya dan kurang menunjukkan kemampuan membuat model matematisnya. Karena mengerjakan soal ini dengan menggunakan prosedur matematis. Meskipun sebenarnya usaha siswa ini dalam menjawab soal tersebut sudah cukup baik di awal. Hanya saja dalam membuat penyimpulannya salah.

Berdasarkan pemaparan di atas, dapat disimpulkan bahwa dengan menggunakan bar model dalam pembelajaran operasi hitung pecahan, kemampuan membuat model matematis siswa menjadi lebih baik. Hal ini sejalan dengan hasil penelitian Zeljic, (2011) yang menyatakan bahwa "student can express their generalisations in various manners: by drawing, arithmetically, verbally and symbolically. Working with numeric patterns which have iconic representation students are able to develop better understanding of number expressions. Elaborating this type of problems, we hope to develop students' abilities preparing them for the following stages of learning mathematics". Artinya bahwa agar siswa dapat menggeneralisasikan suatu masalah matematika, salah satunya adalah dengan menggunakan gambar. Dalam hal ini, bar model dapat membantu siswa dalam mengembangkan kemampuan membuat model matematisnya dan merupakan proses elaborasi yang penting dalam pembelajaran matematika. Jadi, melalui pembelajaran matematika dengan menggunakan bar modelini, kemampuan membuat model siswa menjadi lebih baik dibandingkan dengan 
pembelajaran langsung.

Berdasarkan temuan penelitian tersebut, dapat disimpulkan bahwa penggunaan bar model ini dapat meningkatkan kemampuan membuat model matematis siswa. Hal ini sejalan dengan hasil penelitian Chen (2013), yang mengemukakan bahwa "bar model merupakan metode yang sangat efektif diajarkan untuk memecahkan masalah yang kompleks dengan menggunakan diagram bergambar.

Selain itu, penelitian ini juga sesuai dengan hasil penelitian Mahoney (2012, hlm. 90) yaitu Singapore's model method is potentially effective because it provides a helpful bridge between the representation phase and the solution phase. Jadi, bar model ini sangat efektif untuk membantu siswa dalam merepresentasikan masalah dan menemukan solusinya. Hal ini juga dirasakan oleh peneliti dalam penelitian ini, bahwa penggunaan bar model dapat meningkatkan kemampuan membuat model matematis siswa.

Kaur (2015), mengemukakan dalam temuan penelitiannya bahwa "the model method help students to represent and visualise relationships, when solving number word problems involving the four operations. The concrete-pictorial-abstract approach of teaching mathematics appears to support the development of the models used in the method". Artinya, bar model ini membantu siswa dalam merepresentasikan suatu hubungan menjadi sebuah gambar dalam memecahkan masalah matematika. Selain itu, penggunaan bar modelini juga menjembatani siswa dalam melalui tahaptahap perkembangan koginitifnya dalam rangka membangun pengetahuannya. Hal ini juga sejalan dengan temuan penelitian dalam penelitian ini bahwa dengan menggunakan bar model ini, siswa menjadi lebih mudah dalam menyelesaikan soal-soal matematika non rutin. Karena mereka dibimbing oleh langkah-langkah pembelajaran dengan bar model yang terstruktur dan sistematis.
Sehingga mereka dapat mengembangkan kemampuan membuat model matematisnya dengan baik.

\section{Keterampilan Prosedural Matematis}

Pada rata-rata skor pre-test keterampilan prosedural matematis kelas eksperimen memiliki nilai rata-rata 6,04 dan lebih tinggi dari rata-rata kelas kontrol yang hanya memiliki nilai rata-rata 5,40. Selisih rata-rata antara kedua kelas adalah 0,54, yang apabila dikonversikan dalam bentuk presentase pencapaian kelas eksperimen adalah $60,4 \%$ atau $5,4 \%$ lebih tinggi dari pencapaian kelas kontrol yang hanya memperoleh $54 \%$. Perbedaan pencapaian antara kelas eksperimen dan kelas kontrol ini masil tergolong rendah, sehingga kedua kelas memiliki keterampilan prosedural matematis awal yang relatif sama. Pengolahan data pretest keterampilan prosedural matematis ini dimulai dengan cara melakukan uji normalitas pada kelas eksperimen dan kelas kontrol. Berdasarkan hasil pre-test dan post-test skor terdapat perbedaan antara pencapaian ratarata skor pre-test keterampilan prosedural matematis kelas eksperimen dan kelas kontrol yaitu sebesar $4,8 \%$ presentase ratarata keterampilan prosedural matematis kelas eksperimen lebih tinggi daripada kelas kontrol. Hal ini terlihat dari pencapaian skor pre-test ke post-test kemampuan membuat model matematis pada gambar 4 .

Skor $N$-Gain untuk kelas eksperimen $=$ 0,57 atau $26 \%$ lebih besar dibandingkan ratarata nilai $N$-Gain kelas kontrol $=0,31$ atau $31 \%$.Hasil uji t dengan skor P-value(sig. 2 tailed $)=0,004$ pada taraf signifikansi $\alpha=$ 0,05 karena yang diuji satu arah, sehingga 0,004 dibagi dua hasilnya $0,002<0,05=\alpha$. Kondisi demikian $\mathrm{H}_{0}$ ditolak artinya terdapat perbedaan yang signifikan terhadap skor $\mathrm{N}$-Gain keterampilan prosedural matematis siswa kelas eksperimen dan kelas kontrol.

Berdasarkan hasil uji-t skor $N$-Gain keterampilan prosedural matematis siswa kelas eksperimen dan kelas kontrol dapat disimpulkan bahwa peningkatan 


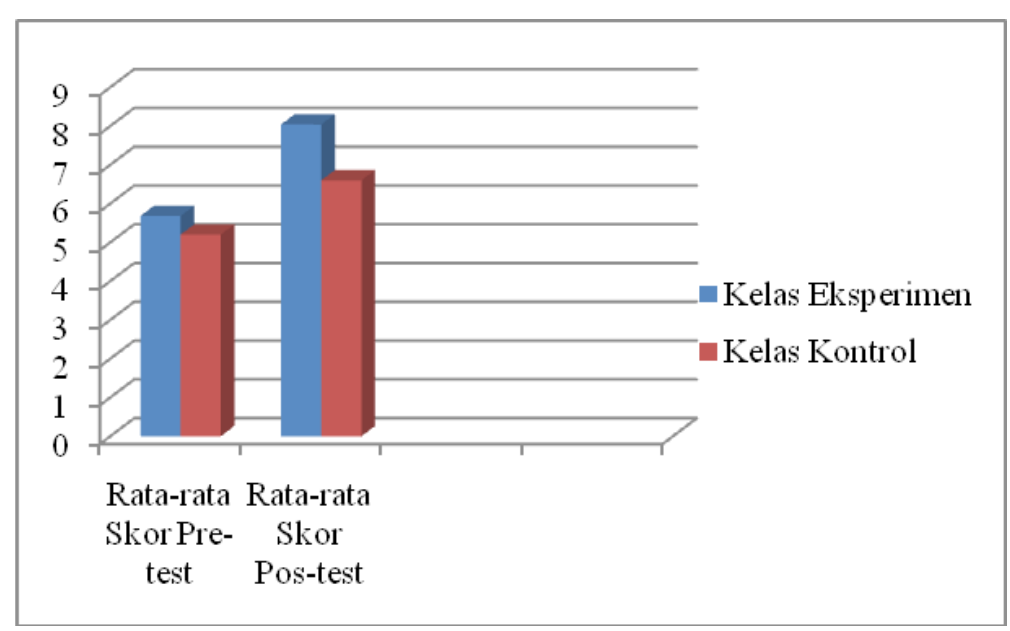

Gambar 4

Rata-Rata Skor Pre-test dan Post-test Keterampilan Prosedural Matematis

keterampilan prosedural matematis dengan menggunakan bar model lebih baik dari siswa yang memperoleh pembelajaran matematika dengan pembelajaran langsung.
Berikut adalah hasil jawaban siswa kelas eksperimen dalam menyelesaikan instrumen post-test keterampilan prosedural matematis:

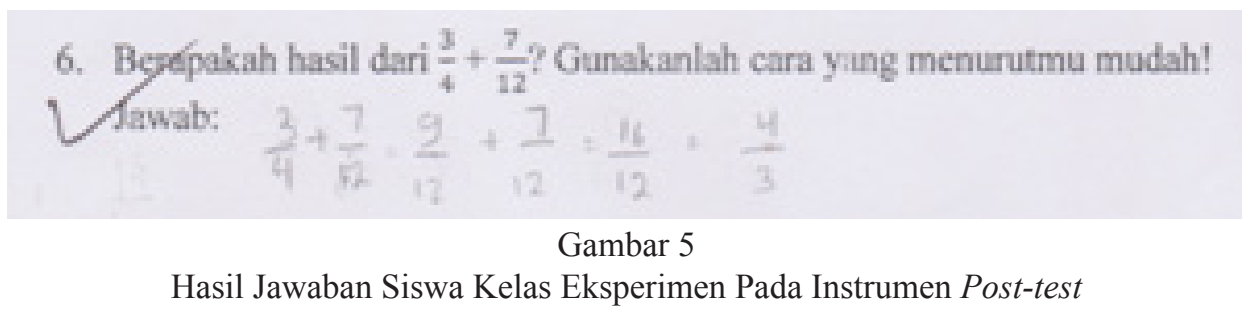

Berdasarkan gambar 5, dapat disimpulkan bahwa, siswa kelas eksperimen ini mengerjakan soal penjumlahan tersebut dengan cara mencari KPK dari penyebutpenyebutnya. KPK dari 4 dan 12 adalah 12 . Sehingga, setiap variabel pecahan yang akan dijumlahkan diubah penyebutnya menjadi 12 . Sehingga, jawabannya tidak terlalu panjang seperti jawaban siswa. Hasil yang didapatkan

langsung pecahan sederhana. Dalam hal ini, kedua siswa kelas eksperimen menunjukkan keterampilan prosedural yang baik dan dapat memanfaatkanprosedur-prosedur matematika dengan baik. Sedangkan untuk kelas kontrol, hasil jawaban siswa dalam mengerjakan instrumen post-test seperti pada gambar 6.

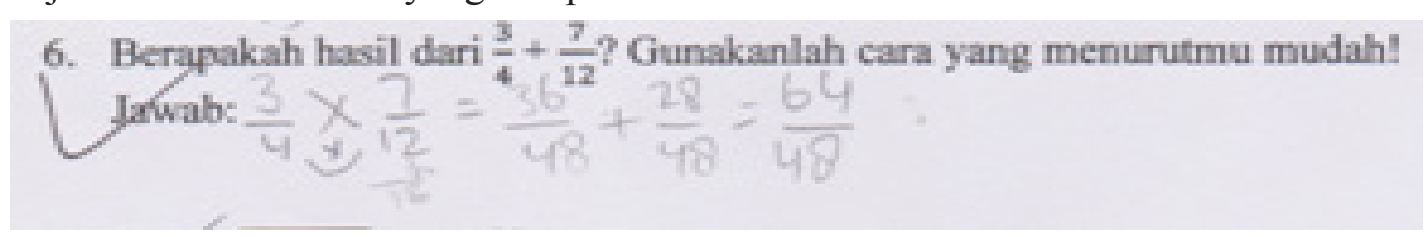

Gambar 6

Hasil Jawaban Siswa Kelas Kontrol Pada Instrumen Post-test

Berdasarkan gambar 6, dapat hasil terakhir jawabannya, siswa ini tidak disimpulkan bahwa pada siswa kelas menyederhanakan jawabannya dan ini poin kontrol ini, jawabannya sudah tepat. Dalam yang membedakan jawaban siswa kelas pengerjaannya, siswa ini menggunakan prosedur yang sesuai yaitu dengan cara eksperimen dengan siswa kelas kontrol. Hal ini disebabkan siswa kelas kontrol mengalikan penyebutnya. Namun, pada kurang memahami bahwa pecahan dapat 
disederhanakan.

Hal ini sejalan dengan temuan penelitian Hiebert (NCTM, 2014) yang menyatakan bahwa "research suggests that once students have memorized and practiced procedures that they do not understand, they have less motivation to understand their meaning or the reasoning behind them". Artinya penelitian yang dilakukan oleh Hiebert telah menunjukkan bahwa siswa yang memiliki kemampuan menghafal yang baik namun tidak mempraktekkan prosedur-prosedur tersebut, mereka memiliki motivasi yang kurang dalam memaknai penalaran mereka. Dalam hal ini, sesuai dengan temuan penelitian dalam tesis ini, siswa baik pada kelas kontrol, sebenarnya menghafal prosedur-prosedur matematika. Sehingga, pada saat mengerjakan soal, mereka tidak menunjukkan proses untuk mendapatkan jawaban, melainkan lebih mementingkan hasil dengan pengerjaan yang cepat.

Berbeda dengan kelas kontrol yang memperoleh proses pembelajaran dengan bar model, mereka menunjukkan bahwa setiap proses pengerjaan soal melibatkan keterampilan prosedural yang dilakukan tahap demi tahap sampai mendapatkan jawaban akhir yang sangat tepat. Hal ini disebabkan karena penggunaan bar modelini membuat siswa menjadi memaknai setiap proses pembelajarannya bukan hanya hasil.

Berdasarkan skor $N$-Gain kelas eksperimen menunjukkan peningkatan dalam kategori sedang. Hal ini berarti penggunaan bar model ini memberikan dampak positif pada peningkatan keterampilan prosedural siswa. Namun, karena waktu yang dilakukan untuk pembelajaran hanya sebentar, sehingga peningkatannya belum optimal.

\section{Ketekunan Belajar Siswa \\ a. Berdasarkan angket}

Dari hasil analisis terhadap 12 butir pernyataan angket ketekunan belajar tersebut dapat disimpulkan nilai yang paling tinggi adalah butir pernyataan nomor 1 dan 6 yaitu 3,72 dan yang nilainya paling kecil adalah butri pernyataan nomor 3 yaitu 3,12. Uji normalitas Shapiro-Wilk memiliki skor $P$-value $($ Sig $)=0,366>0,05$ sedemikian sehingga $\mathrm{H}_{0}$ diterima pada taraf signifikansi $=0,05$. Artinya, skor instrumen ketekunan belajardi kelas eksperimen ini berdistribusi normal.Rata-rata persentase pencapaian skor ketekunan belajar siswa kelas eksperimen adalah $88,75 \%$. Artinya, bahwa siswa kelas eksperimen ini memiliki ketekunan belajar yang sangat baik.

\section{b. Berdasarkan lembar observasi}

Dari ketiga indikator ketekunan belajar, siswa kelas eksperimen menunjukkan sikap yang paling tinggi pada indikator pertama dan kedua yaitu sikap terhadap tujuan dan isi mata pelajaran matematika dan sikap terhadap cara mempelajari matematika masing-masing sebesar $93 \%$ dan 94,5\%. Sedangkan pada indikator yang ketiga yaitu sikap terhadap upaya memperdalam mata pelajaran matematika banyaknya siswa yang menunjukkan hal tersebut sebesar 93\% Artinya, berdasarkan rata-rata skor ketekunan belajar pada setiap indikator tersebut, siswa kelas eksperimen ini memiliki rata-rata skor ketekunan belajar sebesar 94\%. Dalam hal ini, berdasarkan hasil observasi peneliti terhadap ketekunan belajar siswa kelas ekperimen adalah sangat baik. Artinya melalui pembelajaran dengan menggunakan bar model, ketekunan belajar siswa meningkat ke arah yang lebih baik.

\section{c. Secara Keseluruhan}

Berdasarkan angket, rata-rata skor perolehan ketekunan belajar siswa kelas eksperimencukup tinggi. Artinya dengan menggunakan bar model ini sebagian besar siswa sudah memiliki ketekunan belajar yang sangat baik.Ketekunan belajar yang ditunjukkan siswa kelas eksperimen dalam menerima pembelajaran matematika dengan menggunakan bar model ini memperoleh nilai yang sangat baik. Berdasarkan nilai 
rata-rata angket ketekunan belajar, sehingga terlihat jelas bahwa pada pembelajaran matematika dengan menggunakan bar model, siswa cenderung menerimanya dengan baik.

Hal tersebut juga didukung dengan hasil observasi ketekunan belajar siswa yang dilakukan oleh peneliti. Berdasarkan hasil observasi, sebagian besar siswa memiliki ketekunan belajar yang sangat baik. Artinya, data hasil angket ketekunan belajar siswa kelas eksperimen sinkron dengan data hasil observasi ketekunan belajar yang diamati oleh peneliti.Sehingga dapat disimpulkan bahwa dengan menggunakan bar model, ketekunan belajar siswa menjadi lebih baik.

Sehingga dapat disimpulkan bahwa dari lima indikator ketekunan belajar, indikator pertama yakni paham dan yakin pentingnya tujuan dan isi matematika dan indikator ketiga yakni keseriusan dalam mempelajari buku matematika memperoleh skor yang paling tinggi. Sedangkan indikator kedua, keempat dan kelima yang masing-masing berisi kemauan untuk mempelajari dan menerapkan materi matematika, senang membaca atau mempelajari buku matematika dan upaya memperdalam mata pelajaran matematika juga memperoleh skor yang cukup tinggi, di bawah indikator pertama dan ketiga. Artinya secara keseluruhan, berdasarkan angket ketekunan belajar siswa di kelas eksperimen ini mendapatkan nilai yang tinggi. Sehingga dapat disimpulkan bahwa siswa kelas eksperimen ini memiliki ketekunan belajar yang tinggi karena belajar matematika dengan menggunakan bar model.

Hal ini sejalan dengan temuan penelitian Middleton (2015, hlm. 20) yang mengemukakan bahwa "perseverance is not a fixed and immutable psychological trait, but rather that perseverance is determined by the interaction of several anticipatory variables, including students interests, goals, and identity, in response to challenge". Artinya bahwa ketekunan belajar bukanlah sifat psikologis tetap dan tidak dapat berubah, melainkan bahwa ketekunan belajar ditentukan oleh interaksi dari beberapa variabel termasuk minat siswa terhadap proses pembelajaran, dan tujuan dalam menanggapi tantangan. Jadi, sama halnya dengan temuan penelitian dalam tesis ini mengenai ketekunan belajar siswa kelas eksperimen, ketekunan belajar siswa dapat dikategorikan cukup tinggi setelah memperoleh pembelajaran dengan menggunakan bar model. Karena dengan penggunaan bar model ini, siswa dihadapkan pada tantangan untuk dapat bertahan dalam waktu yang cukup lama dalam menyelesaikan suatu masalah matematika.

Sedangkan berdasarkan lembar observasi siswa, pada setiap pertemuannya siswa menunjukkan ketekunan belajar yang tinggi. Hal ini dapat dilihat pada pertemuan pertama sampai terakhir siswa selalu menunjukkan ketekunan belajar dengan memperoleh skor yang tinggi. Meskipun pada beberapa indikator mengalami kenaikan dan penurunan yang tidak begitu signifikan. Hal ini terjadi karena, dalam mengembangkan ketekunan belajar siswa terdapat banyak faktor yang mempengaruhinya. Tidak hanya model pembelajaran saja, namun motivasi belajar siswa juga turut memberikan pengaruh dalam diri siswa. Sehingga, meskipun pada hasil observasi pertemuan terakhir siswa kelas eksperimen ini memperoleh skor ketekunan belajar yang tinggi, tetpai terjadi fluktuasi meskipun tidak terlalu jauh dari skor ketekunan belajar pertemuan sebelumnya. Oleh karena itu, peran guru dalam menjaga dan membangkitkan motivasi belajar siswa dalam rangka mengembangkan ketekunan belajarnya sangatlah penting. Karena siswa akan belajar ketika hatinya merasa senang. Sehingga dapat disimpulkan baik berdasarkan angket mapun lembar observasi siswa, ketekunan belajar siswa kelas ekperimen yang menggunakan bar modeldalam pembelajaran matematika mengenai operasi penjumlahan dan pengurangan pecahan ini adalah tinggi.

Hal ini sejalan dengan temuan penelitian 
Taylor (2015, hlm. 17) mengemukakan bahwa "modeling be useful in identifying students rationale to persevere within a problem-solving task". Artinya bahwa penggunaan bar model ini sangat berguna dalam mengidentifikasi alasan siswa untuk bertahan dalam tugas pemecahan masalah. Maksudnya bahwa dengan menggunakan bar model, siswa akan menunjukkan ketekunan belajarnya dan mampu memecahkan masalah sampai tuntas.

Ketekunan belajar siswa yang dapat dikategorikan baik ini diperoleh siswa karena selama proses pembelajaran dengan menggunakan bar modelini, siswa mendapatkan banyak latihan soal yang berupa LKS dan lembar evaluasi siswa yang dikerjakan baik secara berkelompok maupun individu. Pada setiap pertemuannya, siswa selalu mendapatkan bimbingan dari peneliti sebagai guru agar lebih tekun dalam mengerjakan setiap latihan soal yang diberikan. Melalui langkah-langkah pembelajaran dengan menggunakan bar model ini, setiap siswa mendapatkan bimbingan agar dalam mengerjakan soal tidak terburu-buru membuat simpulan dan agar dapat memahami maksud soal terlebih dahulu.

\section{SIMPULAN}

Terdapat perbedaan peningkatan kemampuan membuat model matematis dan keterampilan prosedural antara siswa yang belajar dengan pembelajaran bar modeldengan siswa yang belajar dengan pembelajaran langsung. Rata-rata skor $\mathrm{N}$-Gain siswa yang belajar dengan pembelajaran bar model lebih tinggi dibanding dengan ratarata skor $N$-Gain siswa yang belajar dengan pembelajaran langsung. Dengan demikian, kemampuan membuat model matematis dan keterampilan prosedural siswa yang belajar dengan pembelajaran bar model lebih baik dibanding dengan siswa yang belajar dengan pembelajaran langsung. Selain itu,siswa yang memperoleh pembelajaran matematika dengan menggunakan bar model memiliki tingkat ketekunan belajar yang tinggi.

\section{DAFTAR RUJUKAN}

Alagic, M., \& Palenz, D. (2006). Teachers explore linear and exponential growth: Spreadsheets as cognitive tools (best paper award from SITE 2004). Journal of Technology and Teacher Education, 14(3), 633649.

Badjeber, R \& Siti, F. (2015). Peningkatan kemampuan koneksi matematis siswa SMP melalui pembelajaran inkuiri model alberta. Jurnal Pengajaran MIPA, Vol. 20, No. 1, hlm. 18-26. ISSN: 1412-0917.

Bruner, J.S (1964) The course of cognitive growth, American psychologist, p 1-15.Diakses dari http://dx .doi.org

Chen, Sandra. (2013). What is Singapore Math?. Diakses dari http://www.ccds.org.

Cheong, Y. K. (2002). The model method in Singapore. The Mathematics Educator Journal, Vol. 6, No. 2 , hlm. 47-64.

English, L. D., \& Watters, J. J. (2005). Mathematical modelling in third-grade classrooms. Mathematics Education Research Journal, 16(3), 59-80.

Fong, Ng Swee\& Lee. K. (2009). Model Method: Singapore Childrens Tool For Representing and Solving Algebra Word Problem. Journal for Research in Mathematics Education. 40 (3), 282-313.

Forsten, Char. (2010). Step-by-step Model Drawing: Solving Word Problems The Singapore Way. Diakses dari www.SDE.com/crystalsprings.

Ginsburg, A., Steven, L., Terry, A., \& Elizabeth, P. (2005). What the United States can learn from Singapores's world-class mathematics system. American Institutes for Research, hlm. 1-139.

Herman, Tatang. (). Tren Pembelajaran Matematika Pada Era Informasi Global. Fakultas Pendidikan Matematika dan IPA UPI. Diakses dari: http//192.168.8.203//upi/.

Kaur, B. (2015). The model method: a tool for representing and visualising relationships. ICMI Study. University of Macau, hlm. 448-455. 
Mahoney, Kevin. (2012). Effects Of Singapore's Model Method On Elementary Student Problem SolvingPerformance: Single Subject Research. Diakses dari Thesis Northeastern University: Boston, Massachusetts.

Middleton, James. A et. al. (2015). Taking the Severe out of Perseverance: Strategies for Building Mathematical Determination. Arizona State University.

Moone, G., \& Cornelis, D. (2007). Fraction action. Diakses dari http//www.nctm.org

National Council of Teachers of Mathematics. (2000). Principiles and standards for school mathematics. Reston, VA: National Council of Teachers Mathematics.

National Council Of Teachers Of Mathematics. (2014). Procedural Fluency in Mathematics: A Position of the National Council of Teachers of Mathematics. Reston, VA: National Council of Teachers Mathematics.

Sugiyono. (2009). Metode penelitian kualitatif, kuantitatif dan RND. Bandung: Alfabeta.

Taylor, Edd. V. (2015). Cultural Considerations in Support of $\quad$ Mathematical Perseverance: The Role of Context Activation. University of Colorado. Hlm. 1- 21.

Thirunavukkarasu, M., \& Senthilnathan, S. (2014). Effectiveness of bar model in enhancing the learning of mathematics at primary level. International Journal of Teacher Educational Research (IJTER) Bharathidasan University, Vol.3, No.1, ISSN:2319-4642.

Turmudi. (2012). Teacher's perception to ward mathematics teaching innovation in Indonesian Junior High School: an exploratory factor analysis. Journal of Mathematics Education, Vol. 5, No. 1, hlm. 97-120.

Wahyudin. (2013). Matematika Dasar: Pengetahuan Bermuatan Pedagogis. Bandung: Mandiri.

Wismath, Shelly et.al (2015). Threshold Concepts in the Development of Problem Solving Skills. The ISSOTL Journal. Vol 3, No.1. Diakses dari http//www.jstor.com

Zeljic, Marijana. (2014). Iconic Representation As Student Sucess Faktor In Algebraic Generalisations.Journal Plus Education. ISSN: 1842-077x . Vol.X No. 1 p 173-184. 